\title{
Oresamenumenamer \\ Jurrat \\ PENDAMPINGAN PROSES PEMBELAJARAN GURU SEKOLAH DASAR MUHAMMADIYAH DI KOTA BENGKULU
}

\author{
Reni Kusmiarti' ${ }^{1}$, Hillyati Mila², Amnah Qurniati ${ }^{3}$ \\ 1 Program Study Pendidikan Bahasa Indonesia , ${ }^{2}$ Program Studi Pendidikan Ekonomi, \\ 3Program Studi Pendidikan Kewarganegaraan , Universitas Muhammadiyah Bengkulu \\ Email: renikusmiarti@umb.ac.id \& hilyati_milla@yahoo.co.id, \& amnaqurniatiamnur@gmail.com
}

\begin{abstract}
ABSTRAK
Guru dituntut kreatifitas dan kemampuan mengembangkan inovasi dalam meningkatkan mutu layanan pendidikan khususnya layanan proses pembelajaran. Kemampuan profesional guru dalam menciptakan pembelajaran yang berkualitas sangat menentukan keberhasilan pendidikan secara keseluruhan. Kualitas pembelajaran sangat bergantung pada kemampuan profesional guru, terutama dalam memberikan kemudahan belajar kepada peserta didik. Masalahnya bagaimana kualitas proses pembelajaran guru sekolah Dasar Muhammadiyah 1 dan 2 di kota Bengkulu setelah diadakan pendampingan. Tujuan pendampingan inidiharapkan adanya perubahan ke arah lebih baik dalam proses pembelajaran. Waktu pelaksanaan satu bulan. Tahapan kegiatan yang dilakukan adalah (1) melaksanakan sosialisasi aspek yang berkaitan dengan proses pembelajaran,(2) melaksanakan pembelajaran oleh guru model dengan pengamatan guru-guru yang lain (3) Melaksanakan refleksi terhadap pembelajaran yang dilakukan oleh guru model di kelas dengan pendampingan oleh tim Pengabdian.Dampak kegiatan pendampingan ini menunjukkan adanya peningkatan kompetensi tentang aspek-aspek yang terkait proses pembelajaran, seperti model pembelajaran, gerakan literasi sekolah, media yang digunakan, langkah-langkah dalam melaksanakan proses pembelajaran dan peningkatan performansi guru dalam proses pelaksanaan pembelajaran.
\end{abstract}

Kata Kunci: Pendampingan, Proses Pembelajaran, Sekolah Dasar

\section{A. PENDAHULUAN}

Undang-Undang Nomor 20 Tahun 2003 tentang Sistem Pendidikan Nasional pasal 1 menyatakan bahwa pendidikan adalah usaha sadar dan terencana untuk mewujudkan suasana belajar dan proses pembelajaran agar peserta didik secara aktif mengembangkan potensi dirinya untuk memiliki kekuatan spiritual keagamaan, pengendalian diri, kepribadian, kecerdasan, akhlak mulia, serta keterampilan yang diperlukan dirinya, masyarakat, bangsa dan negara. Selanjutnya dalam Permendikbud no. 22 tahun 2016 dinyatakan bahwa perubahan paradigma pendidikan di era globalisasi ini mengharuskan adanya perubahan pola pikir (mindset) dan pola tindak (actionset )bagi guru dalam mengelola kelas dan melaksanakan proses pembelajaran, menuntut kreatifitas dan kemampuan 
mengembangkan inovasi dalam meningkatkan mutu layanan pendidikan khususnya layanan proses pembelajaran. Menurut (Ismail, 2010), guru dalam proses pembelajaran memainkan peran penting dalam membantu peserta didik membangun sikap positip dalam belajar, membangkitkan rasa ingin tahu, mendorong kemandirian serta menciptakan kondisi-kondisi untuk sukses dalam belajar. Dengan demikian peranan guru sangat sentral, baik sebagai perencana, pelaksana, maupun sebagai evaluator pembelajaran. Hal ini berarti bahwa kemampuan profesional guru dalam menciptakan pembelajaran yang berkualitas sangat menentukan keberhasilan pendidikan secara keseluruhan. Kualitas pembelajaran sangat bergantung pada kemampuan profesional guru, terutama dalam memberikan kemudahan belajar kepada peserta didik secara efektif dan efesien. Hal ini diperkuat pendapat (Supriadie, Didi dan Deni Darmawan, 2012) yang mengatakan bahwa guru berperan seperti fasilitator, motivator, pemacu, perekayasa pembelajaran dan pemberi inspirasi belajar bagi peserta didik.

Menurut (Mas, 2008) Kualitas guru dapat ditinjau dari proses dan hasil. Segi proses guru dikatakan berhasil apabila mampu melibatkan sebagian besar peserta didik secara aktif, baik fisik, mental, maupun sosial dalam proses pembelajaran. Sedangkan dari segi hasil, guru dikatakan berhasil apabila pembelajaran yang diberikannya mampu mengubah perilaku sebagian besar peserta didik kearah penguasaan kompetensi dasar yang lebih baik untuk mencapai kompetensi standar pembelajaran.

Peraturan Pemerintah nomor 19 tahun 2005 pasal 19 menyatakan bahwa proses pembelajaran pada satuan pendidikan perlu diselenggarakan secara interaktif, inspiratif, menyenangkan, dan menantang. Hal ini diharapkan dapat memotivasi peserta didik untuk berpartisipasi aktif, serta memberikan ruang yang cukup bagi prakarsa, kreativitas, dan kemandirian sesuai dengan bakat, minat, dan perkembangan fisik serta psikologis peserta. (Rusman, 2013) berpendapat bahwa guru merupakan faktor penentu yang sangat dominan dalam pendidikan pada umumnya, karena guru memegang peranan dalam proses pembelajaran, yang merupakan inti dari proses pendidikan secara keseluruhan.

\section{Sekolah Dasar Muhammadiyah 1} pendakian dan Sekolah Dasar Muhammadiyah 2 kebun ros adalah salah satu amal usaha Muhammadiyah yang terletak kota Bengkulu. Guru di kedua sekolah tersebut masingmasing berjumlah 10. Siswa di sekolah SDM 1 Pendakian berjumlah 40 orang, sedangkan di SDM 2 kebun Ros berjumlah 88 Orang. Jumlah siswa tersebut dari kelas satu sampai kelas enam. Dilihat dari jumlah siswa sangat memperihatinkan dan tidak memenuhi persyaratan jumlah ideal siswa dalam satu kelas. Ada beberapa pertanyaan yang terpikirkan oleh penulis, mengapa jumlah 
siswa yang masuk di kedua sekolah dasar tersebut sangat sedikit, apa penyebabnya. Dari Abservasi awal Tim Pengabdian menemukan bahwa kualitas pendidikan di kedua sekolah tersebut belum mampu menghasilkan secara optimal sumber daya manusia yang mampu bersaing. Penyebabnya adalah kualitas tenaga pendidik yang kurang sadar akan pentingnya pembaharuan kualitas dan proses pembelajaran, tidak mengembangkan modelmodel pembelajaran apalagi menerapkan sesuatu yang baru dalam proses pembelajaran dikelas, tidak disiplin, tidak peduli, acuh tak acuh terhadap proses pembelajaran yang dilaksanakan, kurang kreatif. Kualitas proses pembelajaran ini dapat dilihat dari aktivitas belajar dan pemahaman siswa berdasar kompetensi dasar dan indikator yang harus dicapai, serta kinerja guru yang mendukung proses pembelajaran. Mereka masih awam tentang inovasi pembelajaran, model pembelajaran, program literasi sebagai sebuah gerakan yang selalu dituntut dalam kurikulum 2013. Jadi sumber permasalahan adalah kinerja guru sebagai implementasi dari profesionalitas diri dalam upaya menyelenggarakan pembelajaran berkualitas di sekolah.

Berdasarkan uraiandi atas, Tim Pengabdian memandang perlu melakukan pendampingan dalam upaya meningkatkan kompetensi dan performansi guru Sekolah Dasar Muhammadiyah di kota Bengkulu dalam proses pembelajaran. dengan tujuan adanya perubahan ke arah lebih baik dalam proses pembelajaran. Solusi yang ditawarkan dalam memecahkan permasalahan yang ada di kedua Sekolah Muhammadiyah tersebut yaitu mengadakan workshop bagi guru-guru tentang implementasi proses pembelajaran dalam rangka meningkatkan kompetendi dan performansi pelaksanaan proses pembelajaran di sekolah tersebut. Pelaksanaan workshop dilakukan melalui langkah-langkah melaksanakan sosialisasi, (2) melaksanakan pembelajaran oleh guru model dengan pengamatan guru-guru yang lain (3) Melaksanakan refleksi terhadap pembelajaran yang dilakukan oleh guru model di kelas dengan pendampingan oleh tim Pengabdian.

\section{B.METODE KEGIATAN}

Kegiatan pendampingan ini berlokasi di Sekolah Dasar Muhammadiyah 1 Kebun Ros dan Sekolah Dasar Muhammadiyah 1 pendakian, pada bulan September 2018 selama lebih kurang 1 bulan. Metode pelaksanaan kegiatan pendampingan dalam rangka meningkatkan kualitas pembelajaran di Sekolah Dasar Muhammadiyah dengan menempuh langkah-langkah sebagai berikut:

a. Tahap Persiapan: mengkoordinasikan pelaksanaan program dengan mitra dan melakukan persiapan materi workshop

\section{b. Sosialisasi aspek-aspek \\ proses pembelajaran}

Hal-hal yang disosialisasi berhubungan dengan aspek-aspek proses pembelajaran. Materi yang disosialisasikan adalah Standar 
Proses Pendidikan Dasar dan Menengah, yaitu desain pembelajaran, pelaksanaan pembelajaran, Gerakan literasi Sekolah, Model-model Pembelajaran inovatif. Sosialisasi Gerakan literasi Sekolahyaitu konsep literasi, jenis literasi serta bagaimana penerapan literasi dalam pembelajaran di kelas.Sosialisasi model-model pembelajaran inovatif. Target pencapaiannnya adalah guru memahami konsep-konsep yang disosialisasi, sebagai modal guru untuk dapat mengimplementasikannya dalam pembelajaran di kelas

\section{c. Melaksanakan Pembelajaran di Kelas}

Pada tahap ini guru melaksanakan pembelajaran di kelas masing-masing dengan pengamatan guru yang lain dan tim pengabdian. Pelaksaanaan pembelajaran yang dilakukan di kelas merupakan implementasi dari aspek-aspek yang telah disosialisasikan. Guru yang melaksanakan proses pembelajaran di kelas diamati oleh guru yang lain. selesai pembelajaran, mereka bisa melakukan diskusi dan refleksi bersama tentang kekurangan dari proses pembelajaran yang dilakukan. Hasil refleksi bersama tersebut sebagai masukan untuk perbaikan proses pembelajaran selanjutnya.

\section{c. Tahap Refleksi}

Selesai pelaksanaan pembelajaran, guru model dan guru-guru lain melakukan diskusi dan refleksi bersama dengan pendampingan tim pengabdian. Hasil refleksi tentang kekurangan dari proses pembelajaran yang dilakukan. Hasil refleksi bersama tersebut dijadikan sebagai masukan apa yang harus dipertahankan dan apa yang perlu diperbaiki pada pelaksanaan proses pembelajaran selanjutnya. Tahap refleksi ini ini dilaksanakan evaluasi dan refleksi pelaksanaan proses pembelajaran yang dilakukan oleh guru. Pendampingan dan penilaian atas capaian program yang telah dilaksanakan terhadap mitra dalam hal ini guru-guru Sekolah Dasar Muhammadiyah untuk evaluasi seberapa jauh pencapaian pelaksanaan program pendampingan ini.

\section{HASIL , PEMBAHASAN Dan DAMPAK}

\section{Hasil}

\section{a. Sosialisasi aspek-aspek Proses}

\section{Pembelajaran}

Pelaksanaan pendampingan peningkatan kualitas proses pelaksanaan pembelajaran guru sekolah dasar Muhammadiyah dihadiri 14 guru. Pelaksanaan sosialisasi yang dilakukan berjalan lancar dan guru-guru mengikuti tahapan pendampingan tersebut mulai dari pelaksanaan sosialisasi materi, pelaksanaan pembelajaran di kelas maupun pada tahap refleksi.

Pelaksanaan sosialisasi menjelaskan aspek yang berhubungan dengan proses pelaksanaan pembelajaran yaitu standar proses pendidikan dasar dan menengah, gerakan literasi sekolah, model-model pembelajaran inovatif. Sebagian guru-guru tersebut sudah bisa merancang 
rencana pembelajaran karena mereka tergabung dalam MGMP dengan instruktur dari Dinas Pendidikan. Mereka antusias dan semangat mengikuti sosialisasi ini. Banyak guru-guru bertanya tentang materi yang belum mereka pahami. Materi sosialisasi yang disampaikan sangat mendukung dalam pelaksaaan proses pembelajaran guru di kelas karena mencakup proses pelaksanaan pembelajaran yang meliputi kegiatan pendahuluan, kegiatan inti dan kegiatan penutup dengan menggunakan modelmodel inovatif dengan mengimplementasikan pembiasaan literasi.(Hilyati Milla, 2019)

Semangat dan antusias dari guru-guru tersebut memungkinkan materi sosialisasi terserap dengan baik.Beberapa dokumen kegiatan sosialisasipendampingan pelaksanaan proses pembelajaran.

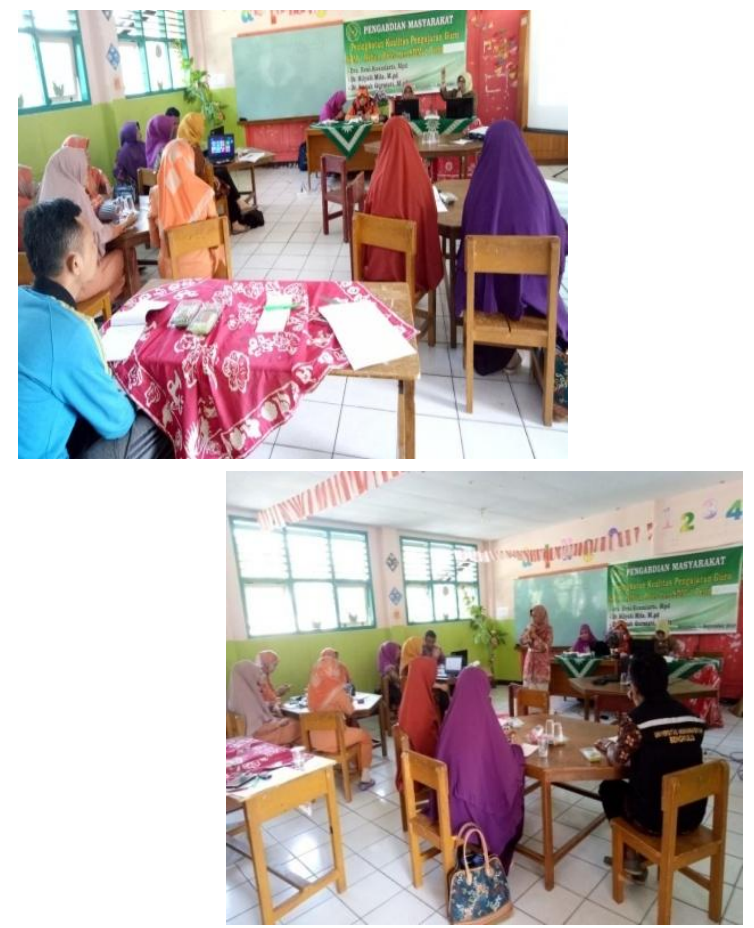

Gambar 1. Tim Pengabdian sedang melaksanakan sosialisasi materi yang berkaitan dengan pelaksanaan proses pembelajaran

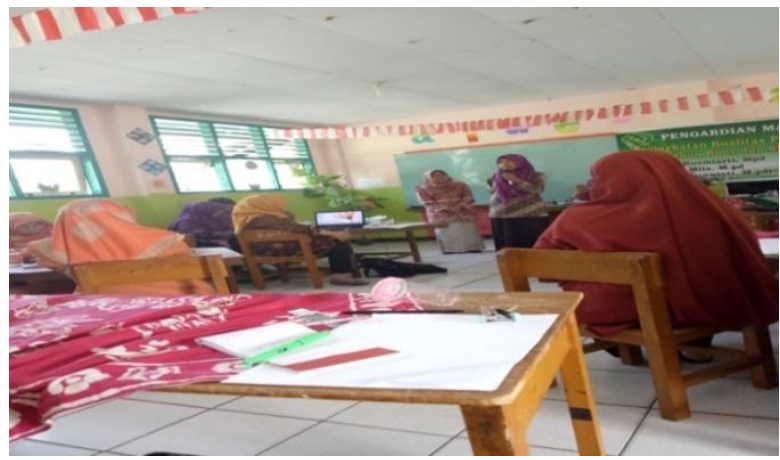

Gambar 2. Diskusi dalam menanggapi dalam proses sosialisasi

\section{b. Pelaksanaan Proses Pembelajaran}

Pelaksanaan proses pembelajaran berjalan dengan lancar. Beberapa guru mengajar di kelas dan guru-guru yang lain mengamati proses pembelajaran yang sedang dilakukan dengan pendampingan tim pengabdian. Pelaksanaan pembelajaran merupakan implementasi dari RPP, meliputi kegiatan pendahuluan, inti dan penutup dengan menerapkan literasi dan metode pembelajaran, serta media.Pengamatan tim pengabdian pada proses pelaksanaan pembelajaran hasilnya sudah membaik dari sebelum dilakukan sosialisasi wor. Kegiatan pendahuluan, guru sudah menyiapkan peserta didik secara psikis dan fisik untuk mengikuti proses pembelajaran, memberi motivasi belajar peserta didik secara kontekstual sesuai manfaat dan aplikasi materi ajar, menjelaskan tujuan pembelajaran atau kompetensi dasar yang akan dicapai, namun pada proses pembelajaran tersebut guru belum mengajukan pertanyaanpertanyaan yang mengaitkan pengetahuan sebelumnya dengan materi yang akan dipelajari sebagai bentuk apersepsi kepada siswa yang 
dapat menuntun kesiapan siswa dalam belajar, juga belum menyampaikan cakupan materi dan penjelasan uraian kegiatan pembelajaran.

Kegiatan inti merupakan proses pembelajaran untuk mencapai kompetensi dasar dan indikator. Kegiatan inti merupakan kegiatan utama dalam proses pembelajaran siswa. Kegiatan inti dalam pembelajaran adalah suatu proses pembentukan pengalaman dan kemampuan siswa secara terprogram yang menggambarkan penggunaaan strategi dan pendekatan belajar yang digunakan guru dalam proses pembelajaran.

Pengamatan tim pengabdian pada proses pelaksanaan pembelajaran, guru model sudah melaksanakan setiap tahapan dalam kegiatan inti. Mereka sudah menerapkan model pembelajaran, sudah mengimplementasikan pembiasan literasi dengan membaca 15 menit sebelum pembelajaran dimulai. Mereka belum melaksanakan proses pembelajaran dengan pendekatan saintifik secara utuh dan terpadu dalam pencapaian indikator yang merupakan ciri pembelajaran dalam Kurikulum 2013. Di dalam Permendikbud Nomor 103 tahun 2014, dijelaskan bahwa ada lima langkah dalam pendekatan santifik yaitu 1) mengamati, (2) menanya, mengumpulkan informasi/mencoba, (4) menalar atau mengasosiasi, dan (5) mengkomunikasikan. Dari kelima langkah saintifik tersebut guru belum melaksanakan kegiatan menalar dan mengkomunikasikan.

Kegiatan penutup dalam proses pembelajaran yang dilakukanguru adalah memberikan umpan balik terhadap proses dan hasil pembelajaran; melakukan kegiatan tindak lanjut dalam bentuk pemberian tugas, baik tugas individual maupun kelompok; dan menginformasikan rencana kegiatan pembelajaran untuk pertemuan berikutnya; melakukan refleksi untuk mengevaluasi seluruh rangkaian aktivitas pembelajaran dan hasil-hasil yang diperoleh; namun belum melakukan umpan balik secara maksimal terhadap proses dan hasil pembelajaran. Beberapa dokumen guru model melaksanakan proses pembelajaran sebagai guru model

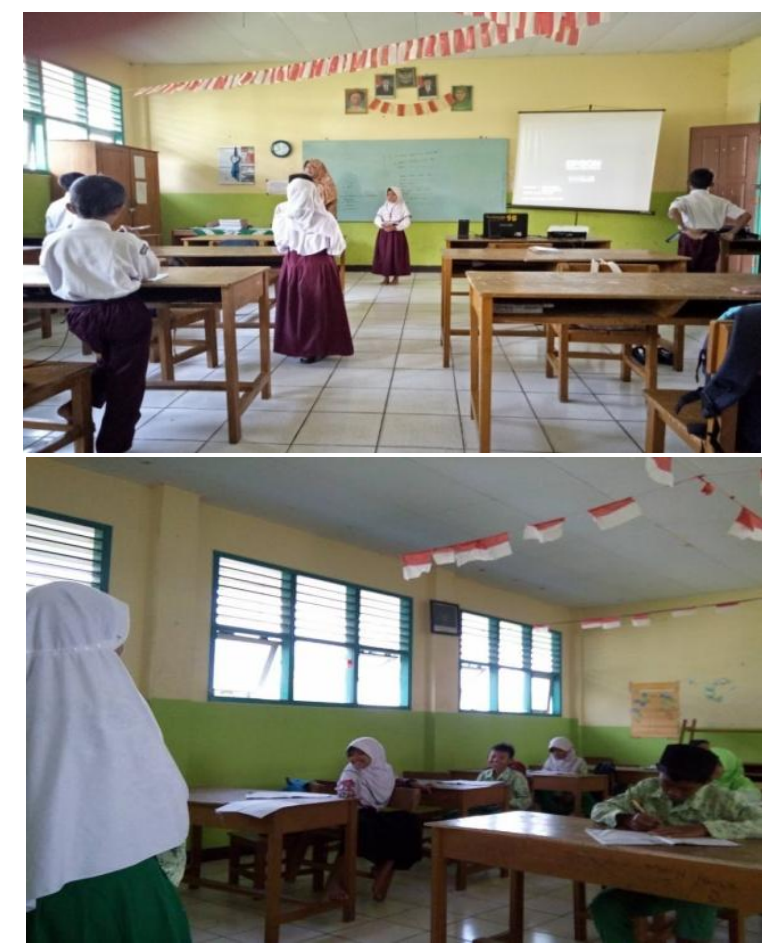

Gambar 3. salah seorang siswa menceritakan apa yang dibacanyadalam proses pembelajaran dengan guru model 


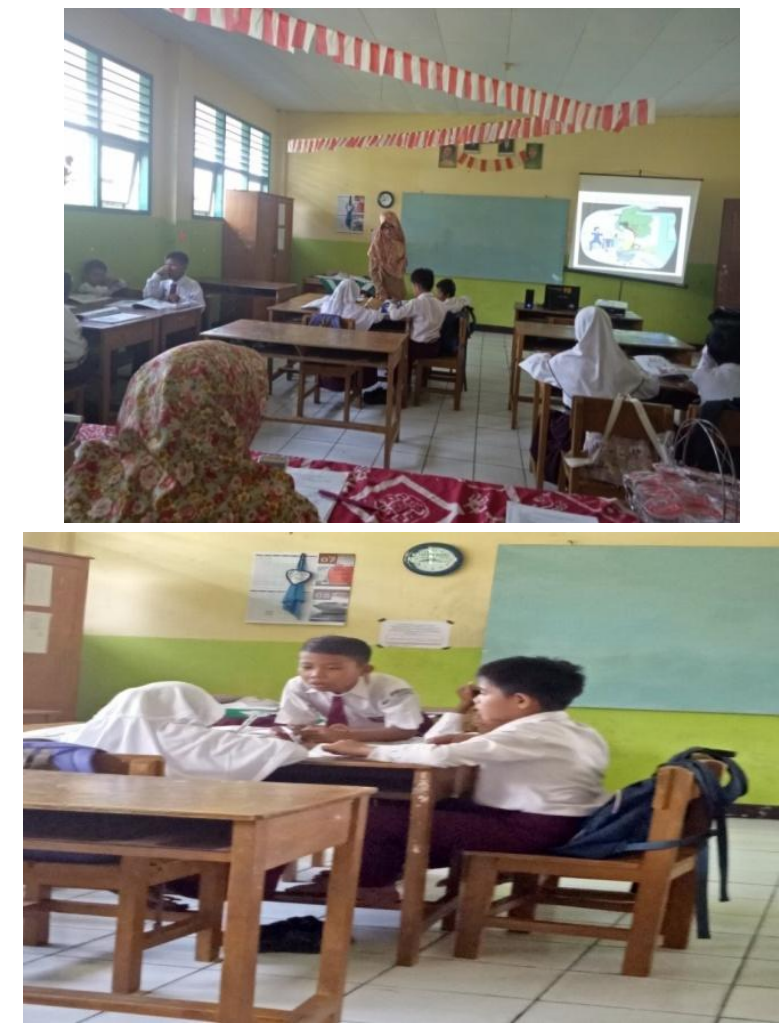

Gambar 4. Siswa berdiskusi dalam proses pembelajaran dengan guru model

\section{Refleksi dan Pembahasan Pendampingan}

Pelaksanaan Proses Pembelajaran Guru

Sekolah Dasar Muhammadiyah Di Kota

\section{Bengkulu}

Setelah

melaksanakan

proses

pembelajaran, guru model dan guru lainnya berdiskusi melakukan refleksi terhadap pelaksanaann proses pembelajaran yang dilakukan oleh guru model. Hasil refleksi banyak hal yang perlu diperbaiki dalam rangka meningkatkan kompetensi dan performansi guru dalam melaksanakan pembelajaran di SD Muhammadiyah 1 dan SD Muhammadiyah 2.

Pada proses pembelajaran yang dinyatakan dalam Peraturan Menteri Pendidikan dan Kebudayaan Nomor 22 Tahun
2016 Tentang Standar Proses Pendidikan Dasar dan Menengah bahwa ada 3 kegiatan yaitu kegiatan pendahuluan, kegiatan inti dan kegiatan penutup. Ketiga kegiatan ini merupakan satu kesatuan yang padu yang harus dilaksanakan dalam proses pembelajaran dalam rangka pencapaian indikator pembelajaran termasuk di dalamnya metode dan strategi yang digunakan, pelaksanaan literasi. Guru model telah melaksanakan proses tersebut namun ada beberapa aspek yang tidak dilaksanakan yang dapat menghambat pencapaian tujuan pembelajaran pada kompetensi dasar tersebut.

Pada kegiatan pendahuluan ada aspek yang terlewatkan dan tidak dilaksanakan oleh guru dalam proses pembelajaran, pada hal aspek tersebut justru dapat menggiring siswa untuk siap mengikuti pembelajaran, yaitu pada aspek mengajukanpertanyaanpertanyaanyangmengaitkanpengetahuan sebelumnya dengan materi yang akan dipelajari sebagai bentuk apersepsi kepada siswa yang dapat menuntun kesiapan siswa dalam belajar,juga tidak menyampaikan cakupan materi dan penjelasan uraian kegiatan pembelajaran.

Pada kegiatan inti, media pembelajaran, dan sumber belajar yang yang digunakan sudah sesuai dengan karakteristik peserta didik dan mata pelajaran. Sudah melaksanakanmodel pembelajaran, metode pembelajaran belum sepenuhnya dilaksanakan, indikator pembelajaran ada yang belum bisa dicapai dalam proses pembelajaran. 
Pendekatan tematik dan /atau tematik terpadu dan/atau saintifik sudah dilaksanakan dalam proses pembelajaran tapi masih belum ideal. Pembelajaran berbasis pemecahan masalah (project based learning) belum dilakukan, karena dikatakan guru dalam wawancara bahwa siswa-siswa di sekolah SDM tersebut kompetensinya belum memadai. pelaksanaan literasi dengan penumbuhan minat baca melalui kegiatan 15 menit membaca sebelum pembelajaran dimulai sudah dilaksanakan, namun dalam proses pelaksanaannya belum sepenuhnya menggunakan pendekatan saintifik secara utuh.

Pada kegiatan penutup guru sudah mengevaluasi seluruh rangkaian aktivitas dan hasil-hasil pembelajaran, menginformasikan rencana kegiatan pembelajaran untuk pertemuan berikutnya, melakukan kegiatan tindak lanjut dalam bentuk pemberian tugas. Yang belum dilaksanakan oleh guru adalah tidak memberikan umpan balik terhadap proses dan hasil pembelajaran, pada hal kegiatan ini merupakan kegiatan penting untuk melihat seberapa jauh pemahaman siswa terhadap substansi materi yang diajarkan.

Hasil refleksi dan pembahasan dapat dikatakan bahwa sebagianguru-guru di sekolah tersebut kompetensi dan performansinya dalam proses pembelajaran mengalami perubahan peningkatan dari sebelumnya, kekurangan disana-sini dapat diperbaiki melalui pembinaan secara berkelanjutan melalui diskusi dengan guru-guru di Sekolah tersebut. Beberapa guru ada juga yang tidak antusias dan semangat mengikuti kegiatan tersebut karena faktor umur dan pengetahuan tentang IT belum memadai. Namun secara nyata dapat dikatakan bahwa dampak dari pendampingan proses pembelajaran guru Sekolah Dasar Muhammadiyah adalah menunjukkan perubahan, peningkatan kompetensi tentang aspek-aspek yang terkait dengan proses pembelajaran dan peningkatan dan perubahan performansi dalam melaksanakan proses pembelajaran di kelas.

\section{Dampak Pendampingan Pelaksanaan}

\section{Proses Pembelajaran Guru Sekolah}

Dasar Muhammadiyah Di Kota Bengkulu

Proses pendampinganpelaksanaan proses pembelajaran guru Sekolah Dasar Muhammadiyah sudah dilakukan, mulai kegiatan sosialisasi aspek-aspek yang terkait dengan proses pelaksanaan pembelajaran, workshop pelaksanaan proses pembelajaran, pelaksanaan refleksi untuk melihat kekurangan dalam pelaksanaan pembelajaran.

Pendampingan ini tentu membawa dampak perubahan pada pelaksanaan proses pembelajaran yang dilakukan oleh guru. Dampak tersebut adalah adanya peningkatan kompetensi aspek-aspek terkait dengan proses pembelajaran seperti kegiatan yang dilakukan pada proses pendahuluan, inti, penutup; pendekatan pembelajaran (saintifik); model pembelajaran; media pembelajaran: teori pelaksanaan literasi dalam proses pembelajaran. Pendampingan ini juga 
berdampak pada peningkatan performansi guru dalam melaksanakan proses pembelajaran. Guru sudah menunjukkan perubahan dalam melaksanaan pembelajaran di kelas, sudah melaksanakan hal-hal yang terkait dengan proses pembelajaran, sudah menggunakan model pembelajaran meskipun belum sempurna. Sudah melaksanakan pendekatan saintifik yang merupakan ruhnya pembelajaran kurikulum 13 meskipun masih ada kekurangan. Kekurangan-kekurangan dari proses pendampingan ini akan terus dipantau dan akan terus dilakukan pengabdian sebagai tindak lanjut dari pengabdian sebelumnya

\section{Penutup}

1. Kesimpulan

Proses pengamatan tim pendamping dan hasil refleksi bersama dapat disimpulkan bahwa:

a. Kompetensi tentang aspek-aspek yang terkait proses pembelajaran, seperti model pembelajaran, gerakan literasi sekolah, media yang digunakan, langkah-langkah dalam melaksanakan proses pembelajaran meningkat dari sebelumnya.

b. Performansi guru dalam proses pembelajaran ada perubahan dari sebelum diadakan pendampingan.

c. Proses pelaksanaan pembelajaran yang dilaksaanakan oleh guru Sekolah Dasar muhammadiyah 1 dan 2 meningkat dari sebelum diadakan pendampingan, walaupun masih banyak yang perlu diperbaiki.

\section{Saran}

Dari hasil pendampingan guru-guru di Sekolah Dasar Muhammadiyah 1 dan 2 disarankan kepada guru-guru tersebut bahwa zaman cepat berubah, menyikapi hal tersebut, guru-guru harus selalu menimba ilmu untuk meningkatkan kompetensi dan performansi diri dalam rangka meningkatkan kualitas diri sebagai pendidik profesional.

\section{Daftar pustaka}

Akbar, Aulia.Membudayakan Literasi dengan Progran 6 M Di Sekolah Dasar. 2017. Jurnal

Pendidikan Sekolah DasarVol 3 No 1 issn 2540-9093

Hilyati Milla, R. K. (2019). Peningkatan Budaya Membaca ( Literasi ) Dalam Masyarakat Di Kelurahan Sumber Jaya Kota Bengkulu. Jurnal Pengabdian Masyarakat Bumi Raflesia, 104-109.

Peraturan Pemerintah nomor 19 tahun 2005 tentang Standar Nasional Pendidikan

Undang-Undang Nomor 20 Tahun 2003 tentang Sistem Pendidikan Nasional

Permendiknas no 22 tahun 2016 tentang Standar Proses Pendidikan Dasar dan Menengah

Ismail, M. I. (2010). Kinerja dan kompetensi guru dalam pembelajaran. Lentera Pendidikan: Jurnal Ilmu Tarbiyah dan Keguruan, 13(1), 44-63. 
Mas, S. R. (2008). Profesionalitas Guru dalam

Peningkatan Kualitas Pembelajaran.

Jurnal Inovasi, 5(2).

Rusman. (2013). Model-model Pembelajaran, Mengembangkan Profesionalisme Guru. Jakarta: Rajawali Pers, 2013. Jakarta: Rajawali Pers.

Supriadie, Didi dan Deni Darmawan. (2012). Komunikasi Pembelajaran. Bandung: Rosdakarya,. 